\title{
Comparison of Batteries Used in Electrical Vehicles (A Review)
}

\author{
Selamat Muslimin ${ }^{1}$, Zainuddin Nawawi ${ }^{2 *}$, Bhakti Yudho Suprapto ${ }^{3}$, Tresna Dewi ${ }^{4}$ \\ 1,2,3,4 Electrical of Engineering, University of Sriwijaya \\ "Corresponding author. Email: nawawi_z@yahoo.com
}

\begin{abstract}
The electric vehicles (EVs) become very popular this day as an effect of the demand in order to reduce automobile emissions. The utilization of energy efficiency to preserve the global environment has been one of public concern. One of current interest is to provide the equipment related to efficient electric power and to reduce air pollution, especially $\mathrm{CO} 2$ emissions. Batteries have been the main energy source for a long time to EVs. Along with time, the technologies of different battery have been invented and adopted. The efficiency of battery is about how much power the battery can charge and discharge concerning battery capacity. The battery management system (BMS) has a crucial role in ensuring bout safety and performance of batteries. In general, there are two categories of batteries based on the ability of recharging, they are primary and secondary battery. The primary battery is type that can only be used once after being fully discharged. The secondary battery is type of battery that able to be recharged after discharging process. In EVs, it requires rechargeable battery with long cycle life, less of energy loss, high power density and sufficient safety level. Some types of batteries that used in EVs such as lithium-ion (Li-ion), lead acid, nickelcadmium $(\mathrm{NiCd})$ and nickel-metal hydride $(\mathrm{NiMH})$, etc. Li-ion battery becomes the most popular power supply implemented for Evs.
\end{abstract}

Keywords: Battery Management System, Li-ion Battery, Electric Vehicle, Lead Acid.

\section{INTRODUCTION}

This day, the electric vehicles (EVs) become very interested because of the demand to reduce automobile emissions. The energy efficiency utilization preserving the global environment has been public concern. One of current interest is to provide the equipment of efficient electric power and to reduce air pollution, especially $\mathrm{CO} 2$ emissions [1].

The technology of battery is one of the keys in electric vehicles (EVs). Many countries, such as America, Japan and Germany, have launched special projects of them improving the performance of batteries which can satisfy the requirements of EVs. Year by years, the performance of battery cells has indicated the significant improvement [2].

Batteries are devices storing energy that consisting of electrochemical cells that convert chemical energy to electrical energy. Batteries are being used for many kinds of purpose, but there are some misunderstanding at consumer that causes to inappropriate selection of battery type in application. This is one basic reason for bad reliability in the applications of batteries. The $\mathrm{Ni}$ MH battery and lithium-ion battery have been widely used in a variety of EVs. Recently, rechargeable lithium-ion (Li-ion) batteries are claimed as the most suitable energy storage device for EVs because of higher energy density and specific power, lighter weight, lower self-discharge rates, higher recyclability and longer cycle life compare to lead-acid, nickelcadmium (Ni-Cd), nickel-metal hydride (Ni-MH) batteries [2][3][4].

Batteries have been the main energy source for EVs for a long time. In many research that have been done, different technologies of battery have been invented and adopted. This process is still going on to achive the desired performance goals [5]. 
Industries and researchers have been providing to consumers the various battery with various characteristics but they have not compiled all the contents related to all the battery types. In this paper will discus about type of batteries that has been used in EVs industry.

\section{TYPE OF BATTERY}

\subsection{Lead Acid (LA) Battery}

Lead Acid (LA) battery was invented in 1859 by Gaston Planté remained the most popular rechargeable battery in the world that was commercially used especially in the automobiles industry. Camille Alphonse Faure has modified the capacity and manufacturing processes of lead-acid batteries in 1881 [7][8].

A lead acid battery is manufactured using lead based on electrodes and grids. The active ingredient is lead oxide that participate in electrochemical charge or discharge include the electrolyte, positive and negative electrodes [3].

\subsection{Nickel Based}

\subsubsection{Nickel Cadmium}

Nickel cadmium was invented in 1989. It is manufactured by depositing active material inside the porous nickel of plated electrode. Nickel cadmium can absorb gases generated during discharge that offered several advantages over lead acid The nickel cadmium battery is known for its good battery cycle life and high internal resistance.

Nickel cadmium (NiCd) became the most suitable battery for the portable electronic equipment in this day. The usage of NiCd battery in the electric vehicles is developed in 1990s. Unfortunately, the market of Nickel Cadmium battery did not expand due to its relatively low range and uncompetitive selling price. [3][7].

\subsubsection{Nickel Metal Hydride}

The nickel metal hydride (NiMH) battery is considered an advanced version of the nickel Ccadmium battery due to the utilize of hydrogen inserted in metallic alloys instead of cadmium at the negative electrode. The nickel metal hydride battery is constantly sealed to prevent hydrogen from leaking. It replaces nickel cadmium in the application of electric vehicles, due to the nickel metal hydride battery's significant improvement in energy density. The utilize of nickel metal hydride battery did not get commercialized in the $1990 \mathrm{~s}$ as the newer technologies of battery were introduced very soon after the nickel metal hydride was developed [3][7].

In early days when researchers started working on nickel metal hydride battery, they did not find it suitable due to the instabilities of metal hydride and as a result which is mainly used in satellites. After discovery of new hydride alloys which provided better stability $\mathrm{NiMH}$ were developed and they offered consid- erable higher specific energy. And another advantage over $\mathrm{NiCd}$ is that it is environmental friendly with no presence of toxic metals in it [3].

\subsection{Lithium Ions}

Lithium-ion Rechargeable batteries is one of the most used and widespread batteries used by electric vehicles nowadays. This type battery was introduced in the 1990s with wide ranges advantage over other battery systems makes it known as the most outstanding quality in new electrochemical industry. The Lithium-ion has high specific energy, and also has a relatively greater travel distance, which is about three times greater than the mileage of the lead acid battery. This several advantages make it competitive with other battery systems [7][8].

Table 1. Battery types comparative analysis [3].

\begin{tabular}{|c|c|c|c|}
\hline Specification & Lead Acid & Nickel Based & Lithium Based \\
\hline Cost & Cheap & Expensive & Average \\
\hline Maintainance Required & High & Low & Moderate \\
\hline Estimated Life Time (Years) & Short & Longer & Long \\
\hline Energy Density (Wh/kg) & $60-110$ & $45-120$ & $110-160$ \\
\hline Application & Solar Power Storage & $\begin{array}{l}\text { Aircraft Applications, } \\
\text { Emergency Lightening }\end{array}$ & $\begin{array}{l}\text { Space Vehicles, Cell } \\
\text { Phones, Laptops }\end{array}$ \\
\hline Depth of Discharge (Apprx) & $20 \%$ for 500 cycles & $20 \%$ for 2500 cycles & $20 \%$ for 300 cycles \\
\hline Charging Tecnique & $\begin{array}{c}\text { Constant Current-Constant } \\
\text { Voltage }\end{array}$ & Constant Current & $\begin{array}{c}\text { Constant Current-Constant } \\
\text { Voltage }\end{array}$ \\
\hline Climate & Severe Effect & Moderate Effect & Great Sustainability \\
\hline
\end{tabular}


Table 2. Comparison among batteries used in EVs [6].

\begin{tabular}{|c|c|c|c|c|c|}
\hline & & & & $\begin{array}{c}\text { Mass of Battery } \\
\text { for EV }\end{array}$ & $\begin{array}{c}\text { Mass Reduction } \\
\text { Compared }\end{array}$ \\
\hline & $\begin{array}{c}\text { Specific Energy } \\
\text { (Wh/Kg) }\end{array}$ & $\begin{array}{l}\text { Energy Density } \\
\text { (Wh/L) }\end{array}$ & $\begin{array}{c}\text { Specific Power } \\
\text { (W/Kg) }\end{array}$ & $\begin{array}{c}\text { to Run a } 100 \mathrm{~km} \\
\text { with } 20 \mathrm{Kwh} / \\
100 \mathrm{~km}\end{array}$ & to Previous Battery \\
\hline Lead Acid & $35-40$ & $80-90$ & 285 & $500-600$ & $0 \%$ \\
\hline $\begin{array}{l}\text { Nikel } \\
\text { Metal }\end{array}$ & $50-70$ & $100-140$ & 200 & $300-400$ & $36.36 \%$ \\
\hline Lithium & $150-200$ & $250-400$ & 260 & $100-140$ & $40 \%$ \\
\hline
\end{tabular}

Lithium-ion batteries didn't suffer from the memory effect as it compared to lead acid and nickel cadmium batteries. Memory effect is used to define the degradation in the battery capacity when it is partially charged and discharged [7][8].

\section{BATTERY IN ELECTRIC VEHICLE (EV)}

The first generation of EVs vanished from the market in the late 1920s. Unfortunately, electric vehicles powered by batteries still couldn't compete to petrol engine vehicles due to short drive range, long recharging time of batteries, and lack of sufficient charging stations. Beside that, Lead Acid and Nickel Cadmium (NiCd) batteries were the only option suitable for EVs during 1900s [6][7].

Due to low specific energy $(30-40 \mathrm{Wh} / \mathrm{kg})$, low energy density (80-100 Wh/L) and limited travel range, Lead Acid batteries lost the EVs market after the rebirth of EVs in the mid-1990s. Nowadays, Lead Acid batteries are used mainly in electric two-wheelers, forklifts and e-rickshaws [8][9].

Nickel metal hydride (Ni-MH) battery were used for hybrid EVs in 1997. Compared to Lead Acid batteries, Ni-MH batteries were relatively more powerful in terms of specific energy $(60-120 \mathrm{Wh} / \mathrm{kg}$ ) and energy density (140-300 Wh/L). Although it has some benefit than Lead Acid batteries, Ni-MH also lost the race with the emergence of Li based batteries [7].

Lithium ions battery introduced in 1991. It leads the revolution of the battery market mainly due to their high specific energy (120-250 Wh/kg) and high energy density $(\sim 600 \mathrm{Wh} / \mathrm{L})$. Nowadays, Lithium ions batteries are the lightest and long-lasting batteries that suitable

Table 3. Comparison battery capacity [6]. for electric vehicles. It makes Lithium ions become the most popular battery in EVs. Lithium-ion battery has obvious advantages such as a long cycle life, high energy capacity and efficiency [7][9].

The travel range of Evs focused on the type and number of batteries used, but some other considerable factors such as field, weather or the driver performance. Energy efficiency is also important to the capacity of battery. The greater of the value rated for the battery efficiency, the more percentage of the energy stored in the battery can be used. A high efficiency battery corresponding to a battery with a high capacity because the charging time for a high efficiency battery is faster so it allows the battery to obtain a greater depth of discharge at the same time [6][7].

Different battery models had different capacity numbers because it made by different manufacturers. The battery efficiancy is about how much the power of the battery can charge and discharge of battery capacity. The technology of Li-ion battery has been proven that it possessed higher energy density than other batteries used for EV. This because $\mathrm{Li}^{-}$ion batteries can retain more electricity as well as to discharge more fuel and also running more devices for long duration at the same time [7][8].

Chian TY et al compared the rated capacity from some batteries used for EVs (Table 3). Lead acid battery was determined from golf car, Ni-MH battery was determined from general motor, and Li-ion battery properties was determined from the current Tesla Model 3. This table shows that the Li-ion based battery has the greatest battery capacity (kWh). Most $\mathrm{f}$ the current EVs are utilizing $\mathrm{Li}$-ion based batteries since $\mathrm{Li}$-ion based batteries have the overall greater performance in EV

\begin{tabular}{cccccc}
\hline & $\begin{array}{c}\text { Energy } \\
\text { Efficiency }\end{array}$ & $\begin{array}{c}\text { Nominal } \\
\text { Voltage }\end{array}$ & $\begin{array}{c}\text { Rated Capacity } \\
\text { (Ah) }\end{array}$ & $\begin{array}{c}\text { Rated } \\
\text { Capacity } \\
\text { (kWh) }\end{array}$ & Distance that \\
\hline (\%) & $(\mathrm{V})$ & & & can Travel \\
\hline $\begin{array}{c}\text { Lead-Acid } \\
\text { Nickel Metal }\end{array}$ & 85 & 6 & 215 & 1.29 & Approx. 22 \\
$\begin{array}{c}\text { Hydrate } \\
\text { Lithium lons }\end{array}$ & 85 & 343 & 77 & 26.4 & $75-150$ \\
\end{tabular}


The battery management system (BMS) become the

Table 4. Comparison of batteries used in EVs based on charging performance [11].

\begin{tabular}{|c|c|c|c|c|c|c|c|c|}
\hline $\begin{array}{c}\text { Battery } \\
\text { Type }\end{array}$ & $\begin{array}{c}\text { Life } \\
\text { (Cycle) }\end{array}$ & $\begin{array}{c}\text { Voltage } \\
\text { (V) }\end{array}$ & $\begin{array}{c}\text { Energy } \\
\text { Density } \\
\left.\text { (W. H. Kg } \mathbf{K g}^{-1}\right)\end{array}$ & $\begin{array}{c}\text { Power } \\
\text { Density } \\
\left(\mathbf{W} . \mathrm{Kg}^{-1}\right)\end{array}$ & $\begin{array}{c}\text { Self- } \\
\text { Discharge } \\
\text { Rate } \\
\left(\% . \text { Month }^{-1}\right)\end{array}$ & $\begin{array}{c}\text { Charging } \\
\text { Efficiency } \\
(\%)\end{array}$ & $\begin{array}{c}\text { Charging } \\
\text { Temperature } \\
\left({ }^{\circ} \mathbf{c}\right)\end{array}$ & $\begin{array}{c}\text { Discharging } \\
\text { Temperature } \\
\left({ }^{\circ} \mathbf{c}\right)\end{array}$ \\
\hline $\begin{array}{l}\text { Lithium } \\
\text { ion } \\
\text { battery }\end{array}$ & $\begin{array}{l}600- \\
3000\end{array}$ & $3.2-3.7$ & $100-270$ & $250-680$ & $3-10$ & $80-90$ & 0 to 45 & -20 to 60 \\
\hline $\begin{array}{c}\text { Lead } \\
\text { acid } \\
\text { battery }\end{array}$ & $\begin{array}{l}200- \\
300\end{array}$ & 2.0 & $30-50$ & 180 & 5 & $50-95$ & -20 to 50 & -20 to 50 \\
\hline $\begin{array}{c}\text { NiCd } \\
\text { battery }\end{array}$ & 1000 & 1.2 & $50-80$ & 150 & 20 & $70-90$ & 0 to 45 & -20 to 65 \\
\hline $\begin{array}{c}\text { NiMH } \\
\text { battery }\end{array}$ & $\begin{array}{l}300- \\
600\end{array}$ & 1.2 & $60-120$ & $250-1000$ & 30 & 65 & 0 to 45 & -20 to 65 \\
\hline
\end{tabular}

application [6].

\section{BATTERY CHARGING PERFORMANCE}

Battery charging is one of significant problem, especially for the devices that dependent to battery such as Electrical Vehicles (EVs). In general, there are two categories of batteries based on the ability of recharging, they are primary and secondary battery. The primary battery can be used once after being fully discharged, and the secondary battery is type of battery that able to be recharged after discharging process [10].

In EVs, however, it requires rechargeable battery with long cycle life, small energy loss, high power density and enough safety level. There are some popular types of batteries used in Evs, they are lithium ion (Liion), lead acid, nickel-cadmium (NiCd) and nickelmetal hydride $(\mathrm{NiMH})$, etc. Kailong et al. reviewed some characteristics for some popular battery types. Table 4 shown that Li-ion battery is significantly better than other types of battery, Li-ion battery is also composed of eco friendly materials without toxic gassing problem and has high safety level [10][11]. main role in ensuring safety and performance of the batteries. Battery needs special repair in the $\mathrm{EV}$ applications. Incorrect operations, such as too high or too low temperature, over charging or discharging will speed up the degradation battery process. However, battery pack in EVs is generally composed of hundreds of battery cells that connected in series or parallel configuration. special repair also needs for such a complicated battery pack [11][12].

The most widely-used charging method is the constant-current constant-voltage (CC-CV) strategy. This strategy applied a constant current is applied to the battery until the terminal voltage reaches a specified value, then the charging current decreases by applying a constant voltage to the terminals of the battery. Another popular traditional charging approach is the MCC that has been successfully developed to charge numerous types of battery. In MCC charging, the multi-stage series of monotonic charging currents are injected into battery during total charging process [12][13].

Battery modelling, internal state estimation and battery charging are the main technologies in the BMS

Table 5. Comparison of charging performance of different battery type [11].

\section{Battery Type}

\section{Charging Performance}

\begin{tabular}{|c|c|}
\hline Lithum Ion & $\begin{array}{l}\text { 1. High temperature be able to improve charging speed but spoil the battery life } \\
\text { 2. In very low temperature, charging is dangerous, well blow freezing }\end{array}$ \\
\hline Lead Acid & $\begin{array}{l}\text { 1. High temperature leads to lower } \mathrm{V} \text {-threshold by } 3 \mathrm{mV} /{ }^{\circ} \mathrm{C} \\
\text { 2. Charging at } 0.3 \text { or less below freezing }\end{array}$ \\
\hline NiMH \& NiCd & $\begin{array}{l}\text { 1. Respectively, charging acceptance decreases from } 70 \% \text { at } 45^{\circ} \mathrm{C} \text { to } 45 \% \text { at } 60{ }^{\circ} \mathrm{C} \\
\text { 2. } 0.1 \mathrm{C} \text { charging rate between }-17{ }^{\circ} \mathrm{C} \text { and } 0{ }^{\circ} \mathrm{C} \\
\text { 3. } 0.3 \mathrm{C} \text { charging between } 0{ }^{\circ} \mathrm{Cand} 6^{\circ} \mathrm{C}\end{array}$ \\
\hline
\end{tabular}


of EVs that needs to be concerned. State of charge (SOC), state of health (SOH) and internal temperature, these states is the main roles in managing the operation of batteries, and need to be monitored but cannot directly measured. Due to its direct impact on the operation safety and service availability of battery, battery charging also importance in BMS. A welldesigned charging strategy will protect batteries against damage. Slow charging has negative effect on the availability of EV utilize, but charging too fast may adversely lead to large energy loss and temperature rise [14][15].

\section{CONCLUSION}

For a long time, batteries have been the primary energy source for EVs. Different battery technologies have been invented and adopted by so researches. The efficiency of a battery is about how much power the battery can charge and discharge in battery capacity. The battery management system (BMS) plays a main role for safety and performance of the batteries. Main technologies in the BMS of EVs is the battery modelling, internal state estimation and battery charging. An effective battery model is crucial in battery behaviour analysis, battery state monitoring, real-time controller design, thermal management and fault diagnosis.

Generally, there are two categoris of batteries based on the ability of recharging, they are primary and secondary battery. In EVs, it requires rechargeable battery with long cycle life, small energy loss, high power density and enough safety level. There are some types of batteries used in EVs such as lithium-ion (Liion), lead acid, nickel-cadmium (NiCd) and nickelmetal hydride $(\mathrm{NiMH})$, etc.

Therefore, Li-ion battery becomes the most popular power supply for EVs. Li-ion battery is significantly better than other types of battery, Lithium-ion battery has obvious advantages such as a long cycle life, high energy capacity and high efficiency also Li-ion battery is also composed of eco-friendly materials without toxic gassing problem and has high safety level.

\section{REFERENCES}

[1] T. Ikeya et al. Multi-step constant-current charging method for an electric vehiclnickel/metal hydride battery with highenergy efficiency and long cycle life. Journal of Power Sources 105. 2002: 6-12

[2] R. Xiong et al.: Critical Review on the Battery State of Charge Estimation Methods for Electric Vehicles. 2018. Vol 6: 1833-1843
[3] Bukhari et al. Comparison of Characteristics Lead Acid, Nickel Based, Lead Crystal and Lithium Based Batteries. 2017: 444-450

[4] Kim J, Oh J, Lee H. Review on battery thermal management system for electric vehicles. Applied Thermal Engineering 149. 2019:192212

[5] Noor et al. A Comprehensive Study of Key Electric Vehicle (EV) Components, Technologies, Challenges, Impacts, and Future Direction of Development. Energies 2017(10): 1217

[6] Chian YT et al. A Review on Recent Progress of Batteries for Electric Vehicles. Int J Appl Eng Res. 14(24). 2019: 4441-4461

[7] Vidyanandan KV. Batteries for Electric Vehicles.1 (38). 2019: 1-7

[8] B. Balagopal, C.S. Huang, M. Chow, 'Effect of Calendar Aging on Li Ion Battery Degradation and SOH', 43rd Annual Conf. of the IEEE Ind. Ele. 2017: 7647-7652

[9] K. Young, C. Wang, L.Y. Wang, and K. Strunz, "Electric Vehicle Battery T echnologies", in Electric V ehicle Integration into Modern Power Networks, R. García-Valle and J.A.P. Lopes (Ed), New York: Springer; 2013.

[10] A. Abdollahi et al. Optimal battery charging, Part I: Minimizing time-to-charge, energy loss, and temperature rise for OCV-resistance battery model. J Power Sources.303. 2016: 388-398

[11] Kailong LIU et al. A Briew On Key Technologies In The Battery Management System Of Electric Vehicles. Front. Mech. Eng. 2018: 1-18

[12] Li J, Han Y, Zhou S. Advancesin Battery Manufacturing, Services, and Management Systems. Hoboken: John Wiley-IEEE Press, 2016

[13] S. M. Rezvanizaniani, Z. Liu, Y. Chen, and J. Lee, 'Review and recent advances in battery health monitoring and prognostics technologies for electric vehicle (EV) safety and mobility', Jr. of Power Sources. 256. 2015: 110-124

[14] R. S. Liu, L. Zhang, X. Sun, H. Liu, and J. Zhang, "Electrochemical Technologies for Energy Storage and Conversion," Electrochem. Technol. Energy Storage Convers., vol. 1-2. 2012

[15] M. Ahman, "Primary energy efficiency of alternative powertrains in vehicles," Energy, vol. 26, no. 11, pp. 973-989, 2001 